\title{
Isolasi dan Uji BSLT Ekstrak Etil Asetat Daun Meranti Sabut (Shore Ovalis (Korth.))
}

Isolation and BSLT test of ethyl acetate extract of Shorea ovalis [Kort.] leaves

\author{
Enda Mora , Musyirna Rahma Nst, Emma Susanti \& Arfan Zasliadi
}

\begin{abstract}
Keywords:
Isolation, characterization,

ethyl acetate extract of Shorea

ovalis (Kort.) leaves, BSLT test.

Kata Kunci: ABSTRACT: Isolation and test of Brine Shrimp Lethality Test (BSLT) of ethyl acetate extract of Shorea ovalis [Kort.]) leaves have been done. The isolation method used was column chromatography by Step Gradient Polarity (SGP). The aim of this research was to isolate the metabolite secondary compound and examine the activity test of Brine Shrimp Lethality Test (BSLT) from ethyl acetate extract of Shorea ovalis [Kort.]) leaves. The result showed that pure compound was $I \neg A$ which characterized by spectrum of IR, H-NMR, C-NMR, HSQC, $H M B C$ and colour reaction of Liebermann-Burchard test. The characterization of the isolate was phytosterol with estimated molecular formula $\mathrm{C}_{27} \mathrm{H}_{48} \mathrm{O}$. Result of BSLT test revealed that of ethyl acetat extract of meranti sabut leaves at 100, 10 , and $1 \mathrm{ppm}$ had value of $L C_{50}=40.45 \mathrm{ppm}$ with death of larva of Artemia salina equal to $56,6 \%$ and was considered as very toxic.

Isolasi,

karakterisasi, ekstraks etil asetat daun meranti sabut, uji BSLT.

ABSTRAK: Telah dilakukan isolasi dan uji BSLT ekstrak etil asetat daun meranti sabut (Shorea ovalis [Kort.]). Isolasi menggunakan metode kromatografi kolom dengan cara Step Gradient Polarity (SGP). Penelitian ini bertujuan mengisolasi senyawa metabolit skunder dan uji BSLT ekstraks etil asetat daun meranti sabut (Shorea ovalis [Kort.]). Dari hasil penelitian didapatkan senyawa murni IA dan dikarakterisasi dengan spektrum IR, H-NMR, C-NMR, HSQC dan HMBC serta reaksi warna menggunakan pereaksi Liebermann-burchard. Hasil karakterisasi senyawa IA disimpulkan adalah senyawa golongan fitosterol dengan perkiraan rumus molekul $\mathrm{C}_{27} \mathrm{H}_{48} \mathrm{O}$. Hasil uji BSLT ekstrak etil asetat daun meranti sabut pada konsentrai 100, 10 dan $1 \mathrm{ppm}$ diperoleh nilai $\mathrm{LC}_{50}=$ 40.45 ppm dengan persen kematian larva Artemia salina sebesar 56,6 \%, tergolong sangat toksik.
\end{abstract}

Sekolah Tinggi IImu Farmasi Riau

Korespondensi:

Enda Mora

(bangendaapt@gmail.com) 


\section{PENDAHULUAN}

Shorea adalah tumbuhan famili Dipterocarpaceae yang merupakan kelompok tumbuhan tingkat tinggi penghuni hutan tropis yang tersebar di sebagian wilayah Indonesia terutama hutan Kalimantan dan Sumatera (1). Beberapa spesies dari genus Shorea adalah penghasil buah tengkawang yang merupakan komoditi ekspor dimana kulit kayunya mengeluarkan getah damar yang dapat digunakan untuk berbagai keperluan, seperti dalam industri obat-obatan dan kosmetika (2). Buah Shorea telah lama dimanfaatkan oleh masyarakat pedesaan sebagai obat tradisional dalam menyembuhkan berbagai macam penyakit, seperti: diare, luka bakar, obat sariawan dan dapat memperlancar peredaran darah. Minyak hasil perasan dari biji buah tengkawang ini digunakan sebagai pengawet nasi dan minyak tradisional (1).

Tumbuhan Shorea ovalis (Kort) dapat diklasifikasikan sebagai berikut (3):

Kingdom : Plantae

Phylum : Tracheophyta

$\begin{array}{ll}\text { Class } & \text { : Magnoliopsida } \\ \text { Ordo } & : \text { Theales }\end{array}$

Famili : Dipterocarpaceae

Genus : Shorea

Spesies : Shorea ovalis (Kort)

Pada bagian batang, daun, dan biji tumbuhan Shorea mengandung metabolit sekunder seperti alfa viniferin suatu trimer stilbenoid dan Hopeaphenol suatu tetramer stilbenoid yang berfungsi sebagai antioksidan $(4,2,5)$. Hasil penelitian sebelumnya, diketahui berbagai jenis senyawa metabolit sekunder dengan bioaktivitas yang sangat menarik diantaranya: senyawa baru turunan oligostilbenoid dari ekstrak metanol kulit batang Shorea gibbosa yang diberi nama diptoindonesin F sebagai antibakteri, antiviral terhadap sel P-388 (6).

Jenis-jenis Dipterocarpaceae tersebar luas terutama di Asia tenggara hingga ke arah barat Srilanka, India utara, dan ke arah timur Filipina dan Indonesia. Di Indonesia sendiri tanaman ini tumbuh alami di daerah Kalimantan, Sumatera, Jawa, Nusa Tenggara, Bali, Sulawesi dan Maluku. Jumlah spesies

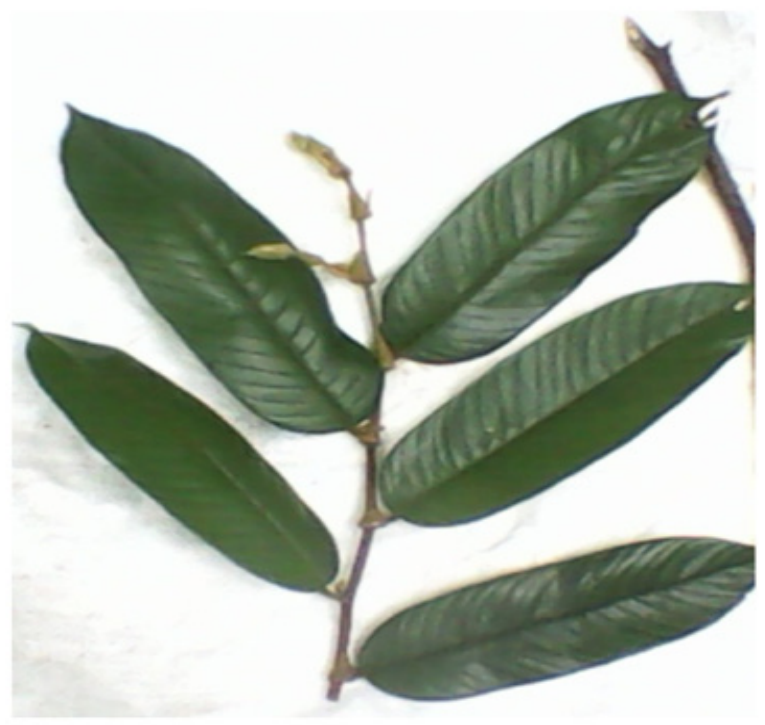

Gambar 1. Daun meranti sabut (Shorea ovalis Kort.) 
yang terdapat di daerah Riau merupakan terbanyak di Sumatera. Berdasarkan hal di atas maka peneliti melakukan isolasi dan uji aktivitas BSLT dari ekstrak etil asetat daun meranti sabut (Shorea ovalis (Kort).

\section{METODE PENELITIAN}

\section{Alat dan Bahan}

Alat yang digunakan dalam penelitian ini adalah alat destilasi, rotary evaporator, neraca analitik, kolom kromatografi, plat KLT GF254, chamber, lampu UV penampak noda, vial, pipa kapiler, alat penentu titik leleh melting point apparatus, spektrofotometer UV-VIS, spektrofotometer IR, NMR dan peralatan gelas yang umum digunakan.

Sampel yang digunakan dalam penelitian ini adalah daun meranti sabut (Shorea ovalis. (Korth)). Bahan yang digunakan adalah n-heksana, etil asetat, metanol, aquadest, asam asetat anhidrat, kloroform, kloroform amoniak, logam magnesium, larutan $\mathrm{FeCl}_{3}$, $\mathrm{HCl} 1 \%, \mathrm{H}_{2} \mathrm{SO}_{4} 2 \mathrm{~N}$, pereaksi LiebermannBurchard, pereaksi Meyer, dan silika gel 60 .

\section{Cara Kerja}

\section{Pengambilan dan Pengolahan Sampel}

Sampel yang akan digunakan adalah daun dari tumbuhan meranti sabut (Shorea ovalis. (Korth) yang diambil di Bukit Suligi Kecamatan Tandun, Kabupaten Rokan Hulu. Daun dari tumbuhan meranti sabut (Shorea ovalis (Korth) terlebih dahulu dibersihkan dari kotoran yang melekat. Kemudian dikering anginkan dan dirajang.

\section{Uji Fitokimia (7)}

Uji pendahuluan kandungan metabolit sekunder dilakukan terhadap daun meranti sabut Shorea ovalis. (Kort). Sebanyak $5 \mathrm{~g}$ sampel dipotong sampai halus, lalu diekstraksi dengan etanol, pada ekstrak ini ditambahkan masing-masing $5 \mathrm{ml}$ air suling dan kloroform lalu dikocok kuat dan dibiarkan beberapa saat sampai terbentuk dua lapisan. Lapisan air digunakan untuk uji senyawa flavonoid, fenolik, dan saponin. Lapisan kloroform digunakan untuk uji senyawa terpenoid, dan steroid.

\section{Uji Flavonoid}

Beberapa tetes lapisan air pada plat tetes ditambah 1-2 butir logam magnesium dan beberapa tetes asam klorida pekat hingga terbentuk warna jingga, merah muda sampai merah menandakan adanya senyawa flavonoid.

\section{Uji Fenolik}

Beberapa tetes lapisan air pada plat tetes ditambah 1-2 tetes larutan besi (III) klorida 1\%. Bila terbentuk warna biru/ungu, berarti terdapat senyawa fenolik.

\section{Uji Saponin}

Lapisan air dalam tabung reaksi dikocok. Apabila terbentuk busa yang bertahan selama 5 menit, berarti positif adanya saponin.

\section{Uji Terpenoid dan Steroid}

Lapisan kloroform disaring melalui pipet yang berisi norit. Hasil saringan di pipet 2-3 tetes dan dibiarkan mengering pada plat tetes. Setelah kering ditambahkan pereaksi Liebermann-Burchard (2 tetes asam asetat anhidrat dan 1 tetes asam sulfat pekat). Terbentuknya warna merah berarti positif adanya terpenoid dan warna hijau-biru 
berarti positif adanya steroid.

\section{Uji Alkaloid}

Sampel daun meranti sabut Shorea ovalis (Korth)sebanyak $5 \mathrm{~g}$ dalam bentuk serbuk, ditambahkan $10 \mathrm{ml}$ kloroform, kemudian ditambahkan $10 \mathrm{ml}$ larutan kloroform beramoniak 0,05 M, diaduk kemudian disaring. Kedalam tabung reaksi tambahkan 10 tets asam sulfat $2 \mathrm{~N}$, kocok selama 2 menit, biarkan hingga terbentuk dua lapisan dan terjadi pemisahan. Ambil lapisan asam (atas) dan tambahkan 1-2 tetes pereaksi Meyer jika terbentuk endapan putih menunjukkan hasil yang positif untuk alkaloid (8).

\section{Ekstraksi Sampel}

Sampel dimaserasi secara bertingkat yang dimulai dri n-Heksana, setelah itu dimaserasi dengan pelarut etil asetat dengan 3 kali pengulangan, kemudian di saring sehingga diperoleh maserat. Maserat dipekatkan dengan rotary evaporator hingga diperoleh ektrak kental etil asetat (9).

\section{Pemisahan Dengan Kromatografi Kolom}

Pemisahan senyawa-senyawa yang ada di dalam ekstrak dilakukan dengan kromatografi kolom dengan diameter ukuran kolom $3 \mathrm{~cm}$, panjang kolom $40 \mathrm{~cm}$ dengan sistem gradien mulai dari n-heksanan 100 $\%$, n-heksanan : etil asetat 1 berbanding 10 hingga metanol $100 \%$ dengan memakai silika gel 60. Pengisian kolom dilakukan dengan membuat bubur silika terlebih dahulu, lalu dimasukkan ke dalam kolom dengan menggunakan corong, kemudian dielusi sampai kerapatan silika di dalam kolom maksimum. Ekstrak yang akan dipisahkan dilakukan preadsorpsi dan dimasukkan dalam kolom. Kemudian dielusi secara bergradien menggunakan pelarut n-heksan, etil asetat, kemudian dengan metanol. Hasil pemisahan ditampung dalam vial $15 \mathrm{ml}$ dan diberi nomor 1 sampai 279 . Hasil kolom dibagi dalam beberapa fraksi dan berdasarkan hasil KLT di peroleh 15 fraksi, hasil fraksi I digabung vial 30 sampai 39. Selanjutnya direksristalisasi, dan diperoleh $17,8 \mathrm{mg}$.

\section{Pengujian Hasil Kromatografi Kolom Dengan KLT}

Hasil pemisahan kromatografi kolom dilakukan uji KLT. Vial-vial yang akan diuji ini diambil secara acak setiap 5 vial, selanjutnya plat KLT dielusi dengan eluen yang sesuai sampai batas atas plat $\mathrm{KLT}$, lalu plat di keluarkan dan dikeringkan. Untuk melihat bercak yang dihasilkan dapat dilakukan memakai plat KLT GF 255 dengan penyinaran lampu UV. Selanjutnya ditentukan Rf dari masing-masing bercak. Vial yang mempunyai harga $\mathrm{Rf}$ yang sama dapat digabungkan menjadi satu fraksi.

\section{Rekristalisasi}

Senyawa hasil kolom direkristalisasi dengan menggunakan dua macam pelarut yang berbeda kelarutannya. Pelarut yang pertama ditambahkan dengan pelarut yang dapat melarutkan hasil isolasi yang jumlahnya sedikit dan selanjutnya ditambahkan pelarut yang tidak melarutkan hasil isolasi, sehingga terjadi rekristalisasi dan pelarut diuapkan (10).

\section{Karakterisasi}

Kemurnian senyawa yangdiperoleh sebanyak $12 \mathrm{mg}$ ditentukan dengan KLT dan pengujian titik leleh menggunakan 
alat melting point apparatus, selanjutnya dilakukan elusidasi struktur menggunakan spektrofotometer Ultraviolet dan Visibel (UV-Vis), IR, dan spektroskopi resonansi magnetik inti (NMR).

Uji Sitotoksik Ekstrak Etil Asetat Daun Meranti sabut (Shorea ovalis (Kort.)) dengan Metode Brine Shrimp Lethality Test (BSLT)

Kista udang Artemia salina ditetaskan dalam wadah pembiakan yang berisi air laut dan telah dilengkapi dengan aerasi oksigen dan lampu, digunakan 48 jam setelah pembentukan larva. Vial uji dikalibrasi sebanyak $5 \mathrm{~mL}$. Pengujian dilakukan dengan konsentrasi 100,10 , dan $1 \mu \mathrm{g} / \mathrm{mL}$. Sebanyak $40 \mathrm{mg}$ sampel uji dilarutkan dalam $4 \mathrm{~mL}$ etanol dan didapatkan larutan induk sampel uji dengan konsentrasi 10.000 $\mu \mathrm{g} / \mathrm{mL}$. Dari larutan induk tersebut dipipet sebanyak $0,5 \mathrm{~mL}$ dan ditambahkan pelarut etanol sampai $5 \mathrm{~mL}$ hingga diperoleh larutan dengan konsentrasi $1000 \mu \mathrm{g} / \mathrm{mL}$. Dari larutan konsentrasi $1000 \mu \mathrm{g} / \mathrm{mL}$, kemudian diencerkan hingga diperoleh konsentrasi $100 \mu \mathrm{g} / \mathrm{mL}, 10 \mu \mathrm{g} / \mathrm{mL}, 1 \mu \mathrm{g} / \mathrm{mL}(11,12)$.

Dari masing-masing konsentrasi dipipet $0,5 \mathrm{~mL}$, dibiarkan pelarut menguap, dilarutkan kembali dengan $50 \mu \mathrm{l}$ DMSO, selanjutnya ditambahkan dengan air laut sampai mencapai batas kalibrasi. Dimasukkan larva Artemia salina ke masing-masing vial sebanyak 10 ekor. Kemudian masingmasing dibuat dalam 3 vial. Kematian larva udang diamati setelah 24 jam. Dari data yang dihasilkan dihitung $\mathrm{LC}_{50}$ dengan metode kurva dan menggunakan tabel probit $(11,12)$.

Untuk kontrol, $50 \mu \mathrm{l}$ DMSO dipipet kedalam vial uji, ditambahkan air laut sampai mencapai batas kalibrasi, dimasukkan larva Artemia salina 10 ekor. Ditambahkan lagi air laut beberapa tetes hingga mencapai kalibrasi (13).

\section{HASIL DAN DISKUSI}

Proses ekstraksi sampel dilakukan dengan metoda maserasi. Pemilihan metoda maserasi ini bertujuan untuk menghindari terjadinya penguraian zat aktif yang tidak tahan terhadap pemanasan (9). Hasil maserasi dipekatkan dengan rotary evaporator, ekstrak kental etil asetat yang diperoleh berjumlah 78 gram dengan rendemen $(3 \%)$ berwarna hijau pekat dan berbau khas. Komponen-komponen senyawa kimia yang terkandung didalamnya dipisahkan menggunakan kromatografi lapis tipis (KLT). Pengamatan dilakukan dibawah lampu UV 254 nm dan UV 366 nm $(14,15)$.

Pemisahan atau isolasi ekstrak etil asetat daun Shorea ovalis (Kort) dilakukan dengan kromatografi kolom sebanyak 3 g menggunakan silika gel sebagai fase diamnya. Ekstrak kemudian dipreabsorsi bersama silika gel hingga kering berbentuk serbuk dan mudah dituangkan ke dalam kolom yang sudah berisi silika. Elusi yang digunakan adalah dengan kepolaran bertingkat atau Step Gradient Polarity (SGP). Dari hasil kromatografi kolom ditampung dalam vial dan dibiarkan menguap. Diperoleh sebanyak 279 vial, kemudian dimonitor dengan KLT yang dilakukan penotolan dari setiap vial dengan jarak 3-5. Pola nodanya diamati dibawah lampu UV. Fraksi yang memilki Rf atau pola noda yang sama digabung sehingga didapatkan 15 fraksi gabungan yang hasilnya ini dimonitoring kembali dengan KLT, 15 fraksi gabungan tersebut diberi label $\mathrm{F} A$ hingga $\mathrm{F} O$.

Dari pola KLT masing-masing fraksi 
yang diperoleh, memperlihatkan adanya senyawa yang memberikan pemisahan pola noktah yang bagus. Fraksi I (vial 30-39) memperlihatkan pola noda yang terpisah sempurna pada KLT, dimana terdapat noktah utama yang bulat, yang terpisah baik, dan memiliki Rf yang ideal, dan juga memperlihat adanya butiran-butiran kristal pada dinding vial sehingga pengerjaan difokuskan pada fraksi I. Kristal pada fraksi I ini kemudian dimurnikan dengan cara rekristalisasi menggunakan pelarut n-heksana dan etil asetat agar terpisah dari pengotornya.

Hasil rekristalisasi didapatkan senyawa murni IA sebanyak 17,8 mg. Senyawa murni IA dilakukakn pengujian titik leleh dan pengujian KLT dengan beberapa eluen yang berbeda. Selanjutnya senyawa murni IA dikarakterisasi secara organoleptis dan spektrofotometri UV, IR dan NMR. Senyawa murni IA yang diperoleh dilakukan uji titik leleh dengan menggunakan alat Melting point apparatus diperoleh nilai titik leleh $135-137^{\circ} \mathrm{C}$. Suatu senyawa dikatakan murni salah satunya apabila selisih harga titik lelehnya kecil atau sama dengan $2^{\circ} \mathrm{C}$ selanjutnya senyawa murni IA dilakukan pengujian dengan KLT memakai beberapa sistem eluen dan didapatkan satu noktah maka senyawa tersebut bisa dikatakan sudah murni.

Senyawa murni IA dilakukan uji spektrofotometer UV-Vis namun senyawa tidak memberikan spektrum serapan maksimum, hal ini dimungkinkan karena tidak adanya gugus kromofor yang terkandung pada senyawa ini. Selanjutnya dilakukan karakterisasi dengan spektrum infra merah memperlihatkan adanya regangan $\mathrm{O}-\mathrm{H}$ dan muncul pada daerah $3344 \mathrm{~cm}^{-1}$ berupa peak yang khas untuk regangan gugus hidroksil. Adanya atom $\mathrm{O}$ yang terikat dengan atom $\mathrm{H}$ didukung oleh peak pada bilangan gelombang $1040 \mathrm{~cm}^{-1}$ yang merupakan gugus C-O. Bilangan gelombang 3086 cm-1 menunjukkan intensitas peak sedang yang berasal dari regangan $=\mathrm{CH}$ alkena, sedangkan pada bilangan gelombang 2963$2848 \mathrm{~cm}^{-1}$ merupakan $\mathrm{CH}$ alifatis $(16,17)$.

Karakterisasi senyawa murni IA menggunakan spektroskopi NMR meliputi 1H-NMR, 13C-NMR, HSQC dan HMBC.

Gambar 2. Hasil KLT kristal senyawa IA dengan pereaksi Lieberman-Bourchard 
Dari Spektrum 1H-NMR senyawa IA, terlihat bahwa pada pergeseran kimia 5,35 (d) memiliki intensitas $1 \mathrm{H}$ yang merupakan $\mathrm{H}$ dari metin $(\mathrm{CH})$ Dan $\delta \mathrm{H} 3,52(\mathrm{~s})$ memiliki $1 \mathrm{H}$ dari $(\mathrm{C}-\mathrm{OH}), \delta \mathrm{H} 2,30(\mathrm{~m})$ memiliki $2 \mathrm{H}$ dari metilen $(\mathrm{CH} 2) ; \delta \mathrm{H} \mathrm{2,02}(\mathrm{m}) 4 \mathrm{H}$ dari $2(\mathrm{CH} 2)$; $\delta \mathrm{H} 1,86(\mathrm{~m}) 6 \mathrm{H}$ dari $3(\mathrm{CH} 2) ; \delta \mathrm{H} 1,68(\mathrm{~m})$ $1 \mathrm{H}$ dari $(\mathrm{CH}) ; \delta \mathrm{H} 1,56(\mathrm{~s}) 2 \mathrm{H}$ dari $(\mathrm{CH} 2)$; $\delta \mathrm{H} \mathrm{1,49(dtd)} 2 \mathrm{H}$ dari $(\mathrm{CH} 2) ; \delta \mathrm{H} \mathrm{1,35(m)} 5 \mathrm{H}$ dari $2(\mathrm{CH} 2$ dan $\mathrm{CH}) ; \delta \mathrm{H} 1,25(\mathrm{~m}) 2 \mathrm{H}$ dari $(\mathrm{CH} 2) ; \delta \mathrm{H} \mathrm{1,11(m)} 1 \mathrm{H}$ dari $(\mathrm{CH}) ; \delta \mathrm{H} \mathrm{1,01(s)}$ $4 \mathrm{H}$ dari $(\mathrm{CH} 3$ dan $\mathrm{CH}) ; \delta \mathrm{H} \mathrm{0,92(d)} 5 \mathrm{H}$ dari $(\mathrm{CH} 3$ dan $2-\mathrm{CH}) ; \delta \mathrm{H} 0,86(\mathrm{~m}) 9 \mathrm{H}$ dari 3 gugus metil $(\mathrm{CH} 3)$ dan $\delta \mathrm{H} 0,86(\mathrm{~s}) 3 \mathrm{H}$ dari gugus metil $(\mathrm{CH} 3)$. Pada spektrum $1 \mathrm{H}-\mathrm{NMR}$ dari senyawa IA memperlihatkan adanya beberapa puncak yang merupakan ciri khas dari suatu golongan senyawa seperti: lupeol, lupenon, simiarenol, $\beta$-amyrin, $\beta$-sitosterol, stigmasterol dan campesterol. Terlihat pada pergeseran kimia $\delta \mathrm{H} 0,0-1,5$ ppm memberikan pola pemisahan puncak yang tidak terpisah sempurna dan hampir berdempetan satu sama lainnya yang merupakan spesifik dan ciri khas dari senyawa golongan terpenoid.

Analisa spektrofotometri 13C-NMR dari senyawa IA memperlihatkan adanya 27 puncak dari atom karbon yang muncul pada pergeseran kimia 140,8; 121,7; 71,8; 56,8; 56,$1 ; 50,1 ; 45,9 ; 42,3 ; 39,8 ; 37,3 ; 36,5 ; 36,2$; 34,$0 ; 31,9 ; 31,7 ; 29,2 ; 28,3 ; 26,1 ; 24,3 ; 23,1$; 21,$1 ; 19,8 ; 19,4 ; 199,0 ; 18,8 ; 12,0$ dan 11,9 ppm. 27 atom karbon ini terdiri dari satu atom karbon kuartener jenuh, satu karbon kuartener rangkap dua dan satu karbon alkena $(18,19)$.

Dari spektrum 13C-NMR senyawa IA ini hanya menunjukkan 27 puncak dan memberikan pergeseran kimia dari 11,9140,8 ppm. Hal ini kemungkinan disebabkan adanya puncak-puncak yang tidak terbaca ataupun adanya beberapa puncak yang muncul saling berhimpitan satu sama lain atau simetris. Oleh karena itu, dilakukan perbandingan-perbandingan analisa data dengan senyawa yang telah diisolasi

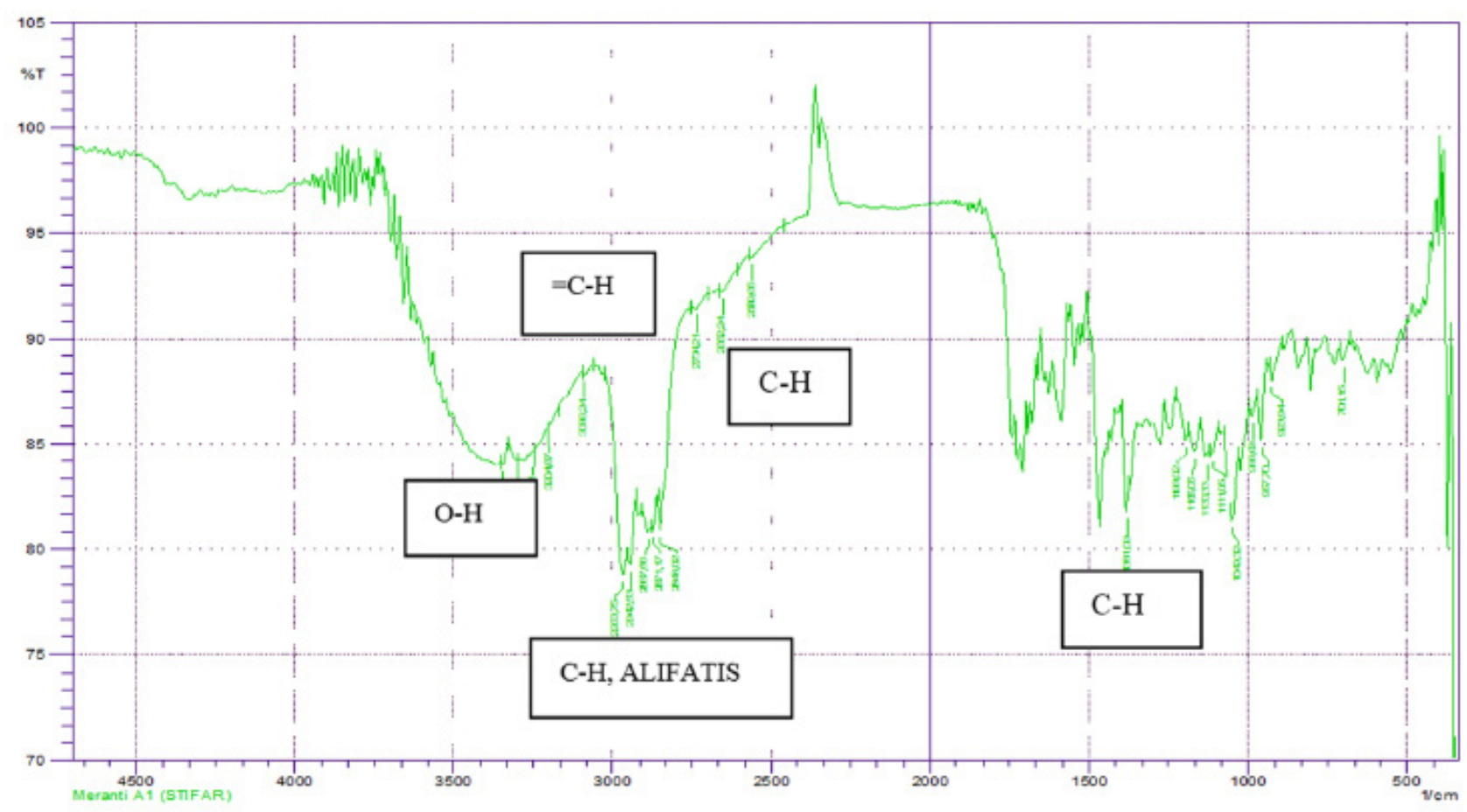

Gambar 3. Spektrum Spektrofotometri Infra Merah Senyawa Murni IA 
sebelumnya.

Korelasi antara karbon dan proton selanjutnya juga dapat dianalisa dari pergeseran kimia karbon $\delta \mathrm{C} \quad 19,8$ ppm dengan $\delta \mathrm{H}(0,86 / \mathrm{N}) ; \delta \mathrm{C} 19,4 \mathrm{ppm}$ dengan $\delta \mathrm{H}$ (1,01/L); $\delta \mathrm{C} 19,0$ ppm dengan $\delta \mathrm{H}(0,86 / \mathrm{N})$; $\delta \mathrm{C} 18,8$ ppm dengan $\delta \mathrm{H}(0,92 / \mathrm{M}) ; \delta \mathrm{C} 12,0$ ppm dengan $\delta \mathrm{H}(0,86 / \mathrm{N})$ dan $\delta \mathrm{C} 11,9 \mathrm{ppm}$ dengan $\delta \mathrm{H}(0,68 / \mathrm{O})$ adalah perpotongan antara karbon dan proton dari jenis karbon metil $(\mathrm{CH} 3)(20,17)$.
Dari hasil pengamatan dan analisa pada spektrum HSQC senyawa IA, diperoleh data yang menyatakan bahwa senyawa ini memiliki 6 atom $\mathrm{C}$ primer, 11 atom C-sekunder, 8 atom C-tersier dan 2 atom C-kuartener. Sehingga dapat disimpulkan jumlah proton dari senyawa ini berjumlah 48 proton. Sedangkan spektrum HMBC memperlihatkan hubungan proton dengan atom karbon tetangga dengan jarak maksimum 4 ikatan. Berdasarkan spektrum senyawa IA dapat dilihat korelasi

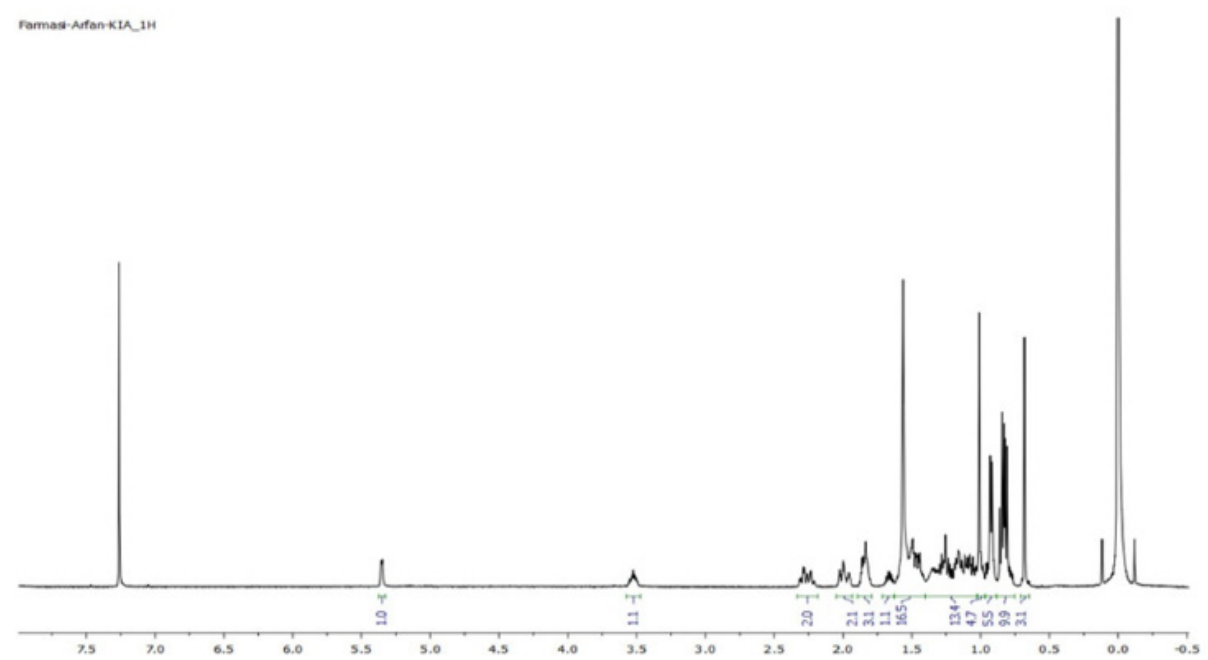

Gambar 4. Spektrum 1H-NMR Senyawa Murni IA.

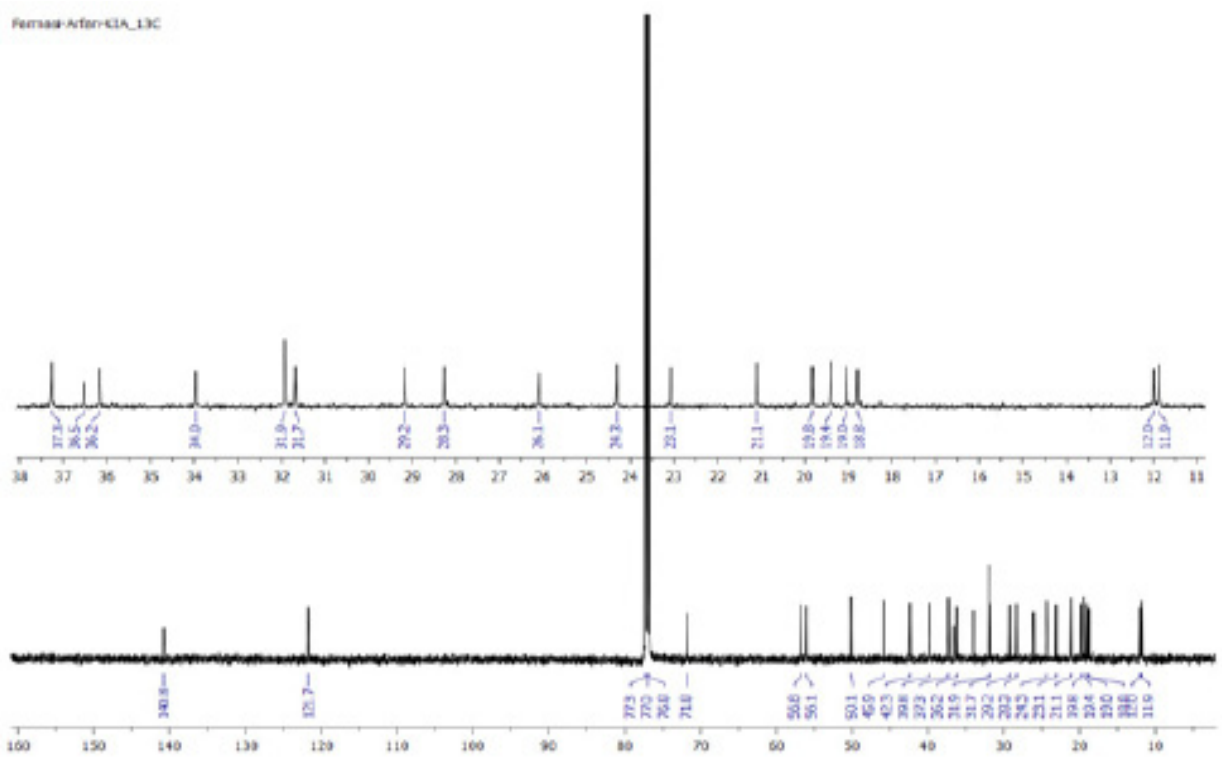

Gambar 5. Spektrum 13C-NMR Senyawa Murni IA. 
(סH5,35) dengan $\delta C ~ 31,7 ; 31,9 ; 36,2 ; 36,5$ dan 42,3 . Korelasi selajutnya $(\delta \mathrm{H} 3,52)$ tidak menunjukkan hubungan dengan $\delta \mathrm{C}$. Korelasi lainnya pada $(\delta \mathrm{H} 2,30)$ dengan $\delta \mathrm{C} 31,7 ; 36,5$; 71,$8 ; 121,7$ dan 140,8 . Selanjutnya $(\delta \mathrm{H} 2,02)$ tidak menunjukkan Korelasi dengan $\delta \mathrm{C}\urcorner$. Kemudian $(\delta \mathrm{H} 1,86)$ dengan $\delta \mathrm{C} 71,8$ dan 140,8. ( $\delta \mathrm{H} \mathrm{1,68)} \mathrm{dengan} \delta \mathrm{C} 19,0 .(\delta \mathrm{H} 1,56)$ memperlihatkan tanpa hubungan dengan бC. $\delta \mathrm{H} 1,49$ dengan $\delta \mathrm{C} 31,9$.

Hasil spektrum HMBC juga dapat dikorelasikan antara atom karbon dengan atom proton yang dimiliki oleh atom karbon tetangga. Korelasi antara masing-masing tetangga atom karbon dapat dengan mudah diinterpretasikan dengan melihat berbagai perpotongan yang terjadi (20). Dilihat dari pergeseran kimia $\delta C$ 140,8 ppm bertetangga dengan atom karbon yang memiliki proton ( $\delta \mathrm{H} \mathrm{Cl} \mathrm{2,30;} \mathrm{E/1,86;} \mathrm{L/1,01} \mathrm{ppm).} \quad$ CC 121,7 bertetangga dengan $(\delta \mathrm{H} \mathrm{C/} \mathrm{2,30);}$ $\delta \mathrm{C} 71,8$ bertetangga dengan $(\delta \mathrm{H} \mathrm{C/} \mathrm{2,30}$

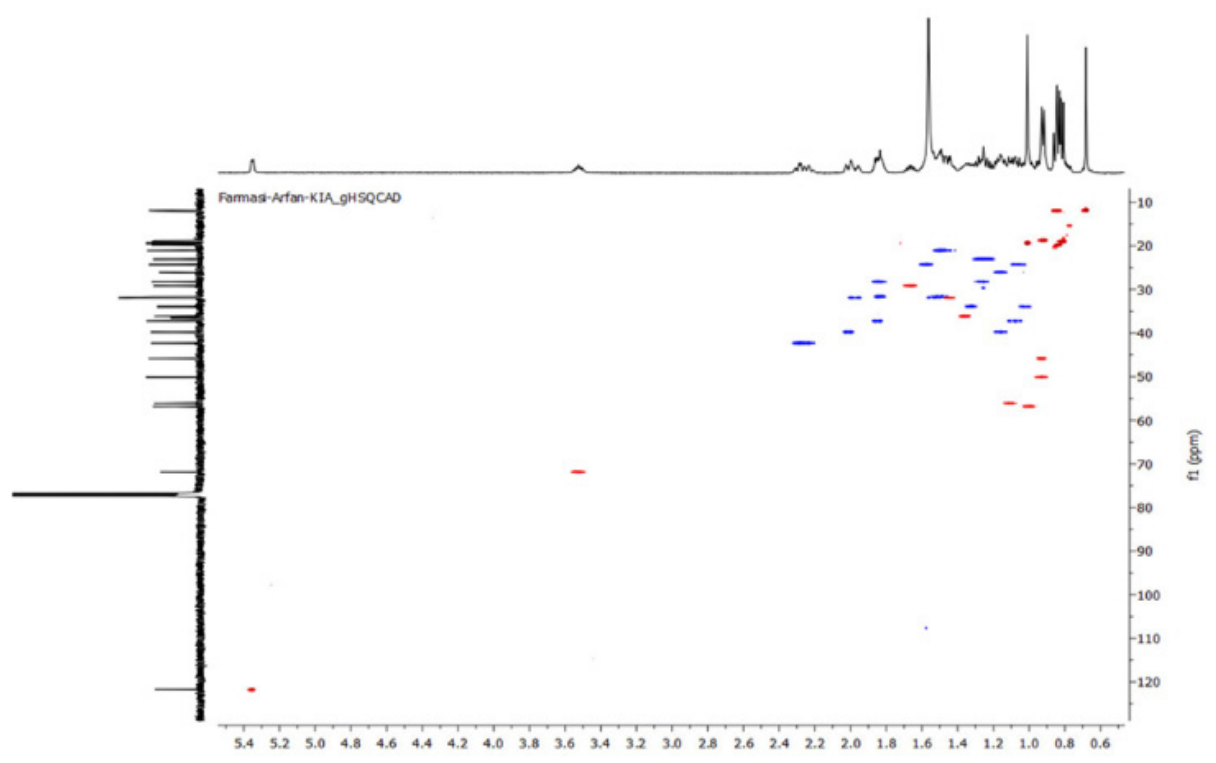

Gambar 6. HSQC Senyawa Murni IA

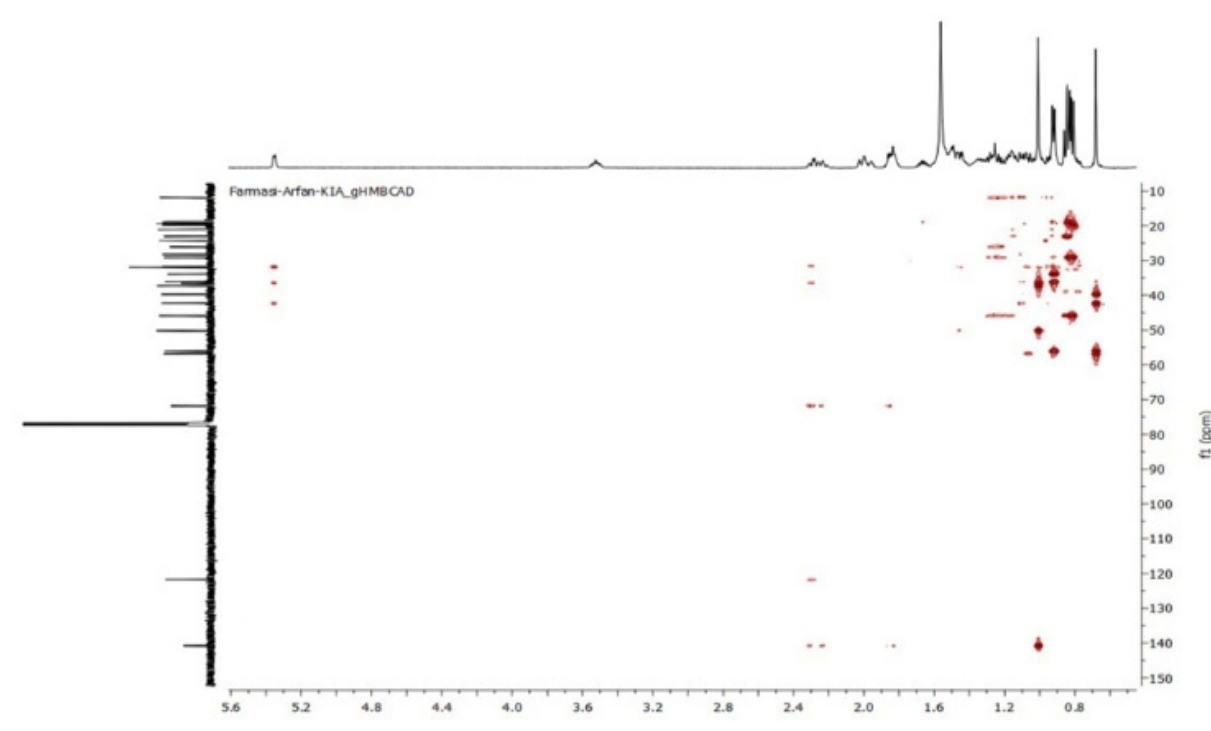

Gambar 7. HMBC Senyawa Murni 
dan $E / 1,68) ; \delta C 56,8$ bertetangga dengan $(\delta \mathrm{H} \mathrm{O} / 0,68) ; \delta \mathrm{C} 56,1$ bertetangga dengan ( $\delta \mathrm{H} \mathrm{M} / 0,92 ; \mathrm{O} / 0,68) ; \delta \mathrm{C} 50,1$ bertetangga dengan $(\delta \mathrm{H} L / 1,01)$; $\delta \mathrm{C} 45,9$ bertetangga dengan $(\delta \mathrm{H} \mathrm{N} / 0,86) ; \delta C \quad 42,3$ bertetangga dengan ( $\delta \mathrm{H} \quad \mathrm{A} / 5,35 ; \mathrm{O} / 0,68) ; \quad \delta \mathrm{C} \quad 39,8$ bertetangga dengan $(\delta \mathrm{H} \mathrm{O} / 0,68) ; \delta \mathrm{C} 37,3$ bertetangga dengan $(\delta \mathrm{H} \mathrm{L/} \mathrm{1,01); \delta C} \mathrm{36,5}$ bertetangga dengan $(\delta \mathrm{H} L / 1,01 ; \mathrm{A} / 5,35$; $\mathrm{C} / 2,30) ; \delta \mathrm{C} 36,2$ bertetangga dengan $(\delta \mathrm{H}$ $\mathrm{K} / 1,11 ; \mathrm{M} / 0,92 ; \mathrm{A} / 5,35) ; \mathrm{C}$ 34,0 bertetangga dengan ( $\delta \mathrm{H} \mathrm{M} / 0,92) ; \delta \mathrm{C} 31,9$ bertetangga dengan ( $\delta \mathrm{H} L / 1,11 ; A / 5,35 ; H / 1,49) ; \delta C 31,7$ bertetangga dengan $(\mathrm{DH} \mathrm{K} / 1,11 ; \mathrm{A} / 5,35 ; \mathrm{C} /$ $2,30) ; \delta C 29,2$ bertetangga dengan $(\delta \mathrm{H}$ $\mathrm{N} / 0,86 ; \mathrm{I} / 1,35 ; \mathrm{M} / 0,92) ; \delta \mathrm{C} 28,3$ bertetangga dengan $(\delta \mathrm{H} M / 0,92) ; \delta C 26,1$ bertetangga dengan $(\delta \mathrm{H} \mathrm{I} / 1,35)$; $\delta \mathrm{C}$ 24,3 bertetangga dengan $(\delta \mathrm{H} \mathrm{M} / 0,92) ; \delta \mathrm{C} 23,1$ bertetangga dengan ( $\delta \mathrm{H} \mathrm{J} / 1,25 ; M / 0,92 ; N / 0,86) ; \delta \mathrm{C} 21,1$ bertetangga dengan ( $\mathrm{HH} \mathrm{M} / 0,92 ; \mathrm{J} / 1,25)$; бC 19,8 bertetangga dengan $(\delta \mathrm{H} N / 0,86)$; $\delta C 19,4$ bertetangga dengan $(\delta \mathrm{H} \mathrm{K} / 1,11)$; $\delta C 19,0$ bertetangga dengan $(\delta \mathrm{H} M / 0,92$; $\mathrm{N} / 0,86 ; \mathrm{F} 1,68) ; \mathrm{\delta} \mathrm{C} 12,0$ bertetangga dengan $(\delta \mathrm{H} \mathrm{I} / 1,35)$ dan $\delta \mathrm{C} 11,9$ bertetangga dengan ( $\mathrm{HH} \mathrm{I} / 1,35 ; \mathrm{J} / 1,25 ; \mathrm{K} / 1,11 ; \mathrm{M} / 0,92)$.

Dari analisa data spektro $1 \mathrm{H}-\mathrm{NMR}$, 13C-NMR, HSQC, HMBC dan perbandingan interpretasi data dengan senyawa hasil isolasi yang telah dilaporkan, senyawa ini memiliki 29 atom carbon dan 48 atom proton dan 1 atom $O$ yang dapat diduga sebagai senyawa $\beta$-sitosterol, namun dari hasil pembacaan NMR senyawa murni IA secara keseluruhan belum dapat disimpulkan struktur lengkapnya, karena masih diperlukan data-data penunjang dari spektrum Massa senyawa IA.

Sedangkan dari hasil uji sitotoksik pada konsentrasi uji 100 ppm terjadi persen kematian hewan percobaan sebesar 56,6\%, $10 \mathrm{ppm}$ sebesar $40 \%$ dan $1 \mathrm{ppm}$ sebesar $23,3 \%$. Konsentrasi yang menyebabkan $50 \%$ kematian hewan percobaan diperoleh pada nilai Lethal konsentrasi (LC50) sebesar 40,45ppm. Suatu ekstrak dianggap memiliki efek positif terhadap kematian larva Artemia salina jika harga $\mathrm{LC}_{50}$ nya $<1000$ ppm (11). Disini terlihat bahwa ekstrak etil asetat kulit batang meranti sabut (Shorea ovalis Kort.) positif sitotoksik terhadap larva Artemia salina.

\section{KESIMPULAN}

1. Hasil isolasi fraksi etil asetat daun Shorea ovalis (Kort) diperoleh senyawa murni IA sebanyak $17.8 \mathrm{mg}$ berupa kristal jarum berwarna putih, mudah larut dalam etil asetat, tidak larut dalam n-heksan, agak sukar larut dalam metanol, memiliki titik leleh $135-137^{\circ} \mathrm{C}$, memberikan perubahan warna merah muda dengan pereaksi LiebermanBourchard, merupakan senyawa golongan fitosterol, dan hasil analisa spektrofotometri IR, 1H-NMR, 13C-NMR, HSQC dan HMBC telah diperoleh data yang menyatakan senyawa IA dari ekstrak Etil Asetat meranti Sabut Shorea Ovalis (korth) adalah senyawa phytosterol yang memiliki 29 atom karbon 48 proton dan 1 atom $\mathrm{O}$.

2. Ekstrak etil asetat daun meranti sabut (Shorea ovalis (Kort.) dengan uji BSLT pada konsentrai 100, 10, dan $1 \mathrm{ppm}$ diperoleh nilai LC50 $=40.45$ ppm dengan persen kematian hewan uji larva Artemia salina sebesar $56,6 \%$ dan tergolong sangat toksik. 


\section{DAFTAR PUSTAKA}

1. Ismarti., 2011, Isolasi Triterpenoid Dan Uji Antioksidan Dari Fraksi Etil Asetat Kulit Batang Meranti Merah (Shorea Singkawang(Miq).Miq), Tesis Pascasarjana Universitas Andalas, Padang.

2. Hakim, E.H., 2002, Oligostilbenoid dari tumbuhan Dipterocarpaceae. Buletin of the Indonesian Socienty of Natural Product Chemistry.2. 1-19.

3. Cronquist, A., 1981, An Integrated System of Classification of Flowering Plants, Columbia, University Press, New York, 316-318.

4. Noviany and Sutopo Hadi, 2009, The Isolation of $\alpha$ - Viniferin, a Trimer Stilbene from Shorea ovalis Blume, Modern Apll.Scie., 3(4); 2009.

5. Sutopo Hadi dan Noviany, 2009, The Isolation of Hopeaphenol, a Tetramer Stilbene from Shorea ovalis Blume, Advances, in Nat. Apll.Scie., 3(1); 107112.

6. Sarayobudiyono, et all, 2008, Oligostilbenoids from Shorea gibbosa andtheir cytotoxic properties agains P-388 cells. J. Nat Med. 62. 195-198.

7. Harborne, J.B., 1987, Metode Fitokimia Penentuan Cara Modern Menganalisis Tumbuhan. Edisi Ke-2. Terjemahan K. Padmawinata dan I. Soediro, Penerbit ITB, Bandung.

8. Farnsworth, N. R., 1966, Biological and Phytochemical Screening of Plants, J. Pharm Sci. 55, 225-276.

9. Anonim, 2000, Standarisasi Ekstrak, Direktorat Jenderal Pengawasan Obat dan Makanan, Departemen Kesehatan Republik Indonesia. Jakarta.
10. Iskandar, A., dan Bantacut, T., 1990, Kristalisasi,Argo Industri. Press,Bandung

11. Meyer, B.N.R., Ferrigni, J.E., Putnam L,B., Jacobsen. D.E., Nicholas, and Laughin,JL., 1982, Brine Shrimp : A Convenient General Bioassay For Active Plant Constituen. J. Of Medical Plant Medica. 45, 31-34.

12. Harefa, F., 1987, Pembudidayaan Artemia salina untuk Pakar Udang dan Ikan, Penerbit Swadaya, Jakarta.

13. Priyanto, 2009, Toksikologi Mekanisme, Terapi Antidotum, dan Penilaian resiko, Penerbit Lembaga Studi dan Konsultasi Farmakologi (Leskonfi,) Depok.

14. Stahl, E., and Michigan., 1985, Analisis Obat Secara Kromatografi dan Mikroskopi,Terjemahan Padmawinata, $\mathrm{K}$, ITB Press, Bandung.

15. Darwis, D., 2000, Teknik Dasar Laboratorium Dalam Penelitian Senyawa Bahan Alam Hayati, FMIPA, Universitas Andalas, Padang.

16. Sastrohamidjojo, H, 1992, Spektroskopi Infra Merah, Liberty Yogyakarta, Yogyakarta.

17. Silverstein, M.R., 1991, Penyidikan Spektrofotometrik Senyawa Organik. Edisi IV, Terjemahan Hartomo. Erlangga, Jakarta.

18. Mohrig, R.J., Hammond, N.C., Schatz., F.P., and Morrill. C.T. 2003. Techniques in Organik Chemistry. W.H. Freeman Company.

19. Pavia., Lampman., and Kriz. 1996. Introduction to Spectroscophy. Second edition. W. B. Saunder, Philadelphia.

20. Crews, P., Rodriguez, J. and Jaspars, M. 1998. Organic Structure Analysis. University of California, Santa Cruz. 